\title{
Biostable aptamers with antagonistic properties to the neuropeptide nociceptin/orphanin FQ
}

\author{
DIRK FAULHAMMER, ${ }^{1,4,5}$ BERND ESCHGFÄLLER, ${ }^{1,4,6}$ SANDRA STARK, ${ }^{1,4,7}$ PETRA BURGSTALLER, ${ }^{1,8}$ \\ WERNER ENGLBERGER, ${ }^{2}$ JEANNETTE ERFURTH ${ }^{1,9}{ }^{1,9 R A N K ~ K L E I N J U N G, ~}{ }^{1,10}$ JOHANNA RUPP, ${ }^{3}$ \\ SEBASTIAN DAN VULCU, ${ }^{3}$ WERNER SCHRÖDER, ${ }^{1}$ STEFAN VONHOFF, ${ }^{1}$ HERMANN NAWRATH, ${ }^{3}$ \\ CLEMENS GILLEN, ${ }^{2}$ and SVEN KLUSSMANN ${ }^{1}$ \\ ${ }^{1}$ NOXXON Pharma AG, 10589 Berlin, Germany \\ ${ }^{2}$ Grünenthal $\mathrm{GmbH}$, Molecular Pharmacology, 52078 Aachen, Germany \\ ${ }^{3}$ Department of Pharmacology, Johannes Gutenberg Universität Mainz, 55101 Mainz, Germany
}

\begin{abstract}
The neuropeptide nociceptin/orphanin FQ (N/OFQ), the endogenous ligand of the opioid receptor-like 1 (ORL1) receptor, has been shown to play a prominent role in the regulation of several biological functions such as pain and stress. Here we describe the isolation and characterization of N/OFQ binding biostable RNA aptamers (Spiegelmers) using a mirror-image in vitro selection approach. Spiegelmers are L-enantiomeric oligonucleotide ligands that display high affinity and specificity to their targets and high resistance to enzymatic degradation compared to D-oligonucleotides. A representative Spiegelmer from the selections performed was size-minimized to two distinct sequences capable of high affinity binding to N/OFQ. The Spiegelmers were shown to antagonize binding of N/OFQ to the ORL1 receptor in a binding-competition assay. The calculated IC ${ }_{50}$ values for the Spiegelmers NOX 2149 and NOX 2137a/b were $110 \mathrm{nM}$ and $330 \mathrm{nM}$, respectively. The competitive antagonistic properties of these Spiegelmers were further demonstrated by their effective and specific inhibition of G-protein activation in two additional models. The Spiegelmers antagonized the N/OFQ-induced GTP $\gamma \mathrm{S}$ incorporation into cell membranes of a CHO-K1 cell line expressing the human ORL1 receptor. In oocytes from Xenopus laevis, NOX 2149 showed an antagonistic effect to the N/OFQ-ORL 1 receptor system that was functionally coupled with G-protein-regulated inwardly rectifying $\mathrm{K}^{+}$ channels.
\end{abstract}

Keywords: Spiegelmer; nociceptin; neuropeptide; biostable aptamer; RNA, pain

\section{INTRODUCTION}

The neuropeptide nociceptin/orphanin FQ (N/OFQ) is the endogenous agonist of the $\mathrm{G}$ protein-coupled opioid receptor-like 1 (ORL1) receptor (Meunier et al. 1995; Reinscheid

\footnotetext{
${ }^{4}$ These authors contributed equally to this work.

Reprint requests to: Sven Klussmann, NOXXON Pharma AG, MaxDohrn-Str. 8-10, 10589 Berlin, Germany; e-mail: sklussmann@noxxon. net. fax: +49-30-7262 47243 .

Present addresses: ${ }^{5}$ Amersham Buchler GmbH \& Co. KG, Fraunhoferstrasse 7, 85737 Ismaning, Germany; ${ }^{6}$ Novartis Pharma AG, WKL-490.1.55, 4002 Basel, Switzerland; ${ }^{7}$ Philogen S.r.l., La Lizza 7, 53100 Siena, Italy; ${ }^{8}$ P.B., Am Marktplatz 8, 82152 Planegg, Germany; ${ }^{9}$ Degussa AG, CVPH-BT, Rodenbacher Chaussee 4, 63457 Hanau-Wolfgang, Germany; ${ }^{10}$ MicroDiscovery GmbH, Marienburger Strasse 1, 10405 Berlin, Germany.

Abbreviations: BSA, bovine serum albumin; DEPC, diethylpyrocarbonate; dNTP, deoxyribonucleotide triphosphate; HBSS, Hank's balanced salt solution; NTP, ribonucleotide triphosphate; PBS, phosphate buffered saline; PCR, polymerase chain reaction; PMSF, phenylmethylsulfonyl fluoride; WGA, wheat germ agglutinin.

Article and publication are at http://www.rnajournal.org/cgi/doi/ 10.1261/rna.5186504.
}

et al. 1995). N/OFQ is distributed throughout the central nervous system (Darland and Grandy 1998; Neal et al. 1999). ORL1 is found both in the central nervous system and peripheral tissues (Meunier 1997; Monteillet-Agius et al. 1998). It was shown that N/OFQ plays a prominent role in the regulation of biological functions such as pain, anxiety, motor impairment, and others (Meunier 1997, 2000; Darland et al. 1998; Griebel et al. 1999; Calo et al. 2000a). This broad physiological profile opens a wide spectrum of potential therapeutic applications (Henderson and McKnight 1997; Griebel et al. 1999; Grisel and Mogil 2000; Mollereau and Mouledous 2000; Reinscheid et al. 2000).

The role of N/OFQ in the modulation of pain is controversially discussed (Mogil and Pasternak 2001; Calo et al. 2002). The nociceptive effects depend on the site of administration. Intrathecal (i.t.) administration of N/OFQ was reported to result in an antinociceptive response (Tian et al. 1997; Kamei et al. 1999; Calo et al. 2000c), whereas intracerebroventricular (i.c.v.) administration results in a hyperalgesic response (Meunier et al. 1995; Reinscheid et al. 1995). 
N/OFQ neutralizing antibodies (Tian et al. 1998; Tian and Han 2000) caused a pronociceptive effect if administered spinally and an increased analgesic effect following i.c.v. injection (Tian and Han 2000). The peptide [Nphe ${ }^{1}$ N/OFQ- ${ }_{(1-13)}-\mathrm{NH}_{2}$ was employed as a useful tool and has been shown to reverse the supraspinal hyperalgesic action of N/OFQ (Calo et al. 2000b; Rizzi et al. 2000).

In the past decade, it has been shown that oligonucleotides can fold into complex three-dimensional structures comparable to proteins. Such oligonucleotide ligands, also called aptamers, are being isolated from combinatorial nucleic acids libraries by means of in vitro selection (Ellington and Szostak 1990; Robertson and Joyce 1990; Tuerk and Gold 1990). This method has been employed to identify aptamers for various target molecules (Wilson and Szostak 1999; Brody and Gold 2000; James 2000). Displaying high affinity and specificity to a given target, aptamers are regarded as oligonucleotide analogs of antibodies and are therefore suited for diagnostic and therapeutic applications (Jayasena 1999; Brody and Gold 2000; Toulme 2000). However, progress in the development of nucleic-acid-based therapeutics was hampered by their limited biological stability. One possibility to enhance biological stability is the introduction of modified nucleotides into the sequences during (Lin et al. 1994; Kubik et al. 1997; Pagratis et al. 1997) and after in vitro selection (Gold 1995; Green et al. 1995). An elegant alternative is the application of enantiomeric L-nucleic acids (Urata et al. 1992; Klussmann et al. 1996; Nolte et al. 1996; Williams et al. 1997). Here, aptamers are raised against the synthetic enantiomer of the target molecule. After chiral inversion, the mirror image of the oligonucleotide ligand (termed Spiegelmer) binds to the natural configuration of the target. This method results in oligonucleotide ligands that combine high target affinity and specificity with an exceptional resistance toward nuclease activity. This mirror-image in vitro selection was successfully applied for the generation of RNA and DNA Spiegelmers as well as D-peptides (Vater and Klussmann 2003).

We generated N/OFQ binding Spiegelmers in order to pursue studies about the physiological actions of N/OFQ. Although a series of agonists and antagonists of the ORL1 receptor as well as anti-N/OFQ antibodies exist (Mogil and Pasternak 2001; Calo et al. 2002), none of these show the specificity and potency necessary for their development as therapeutics. We demonstrate that biostable Spiegelmers have a high potential as an alternative therapeutic substance class for the N/OFQ-ORL1-receptor system.

\section{RESULTS}

\section{In vitro selection of RNA ligands to $D-N / O F Q$}

RNA ligands with high affinity to D-N/OFQ were isolated in several in vitro selection experiments employing two differ- ent RNA pools. The RNA pools containing 40 and 60 random sequence positions were incubated at $25^{\circ} \mathrm{C}$ with an affinity resin derivatized with D-N/OFQ. Nonbinding molecules were removed by washing the resin with selection buffer and specifically bound species were eluted by using a $400 \mu \mathrm{M}$ solution of the peptide in selection buffer. The stringency of the selection was increased by progressively raising the wash volume $(1.9-4.0 \mathrm{~mL})$ and by additionally using an affinity resin that contained the peptide at a lower concentration (100-25 $\mu \mathrm{M})$ in later rounds. After nine cycles of selection and amplification, the amount of N40 RNA pool that was retained on the resin containing $100 \mu \mathrm{M}$ peptide had increased significantly (27.6\% bound) compared with the starting pool in which $0.6 \%$ was retained under the same conditions. The N60 RNA pool showed $18.5 \%$ binding to the resin after nine rounds of selection. The enriched N40 pool was cloned and sequenced (R01). The sequence analysis revealed that the library was still diverse. As a consequence, the selection was continued under more stringent conditions by using an affinity resin that contained $25 \mu \mathrm{M}$ peptide in addition to increased washing. As a result, binding to the resin of both pools dropped to $3.3 \%$ and $2.2 \%$, but was restored in the course of the next three rounds to $10.7 \%$ and $12.3 \%$, respectively. After 13 cycles of selection and amplification, aliquots of both pools were cloned and sequenced (R02 and R03, respectively).

Sequences of the various enriched pools revealed three sequence families and a number of sequences with no relationship to any other sequence (Fig. 1). All sequences were rich in $G$ and often characterized by long $G$ stretches. Two sequence motifs (families 1 and 3) were shared by clones from both the N40 and N60 pools. A comparison of the sequences derived from rounds 9 and 13 of the N40 pool (R01 and R02) revealed that selection at a lower peptide concentration led to a depletion of sequence variety as expected.

\section{Characterization and truncation of RNA aptamers recognizing free $\mathrm{D}-\mathrm{N} / \mathrm{OFQ}$}

To identify RNA ligands that recognize free D-N/OFQ, fluorescence polarization was applied in the screening process employing fluorescein-labeled D-N/OFQ. Only a small number of clones had a measurable affinity to free D-N/ OFQ in the concentration range used $\left(K_{D}<100 \mu \mathrm{M}\right)$. Most of the RNA ligands that had shown a strong affinity to immobilized D-N/OFQ failed to recognize the free peptide. Binding species were either members of families 1 or like nucleic acid ligand R03-G8, not related to any other sequence family. Their observed equilibrium binding constants were in a range between 0.2 and $3 \mu \mathrm{M}$ (Table 1 ). The specificity of isolated RNA ligands was determined by measuring the affinity of nucleic acid ligand D-R03-G8 to natural L-N/OFQ and L-dynorphin A. Using fluorescein-labeled L-N/OFQ as a tracer, binding of D-R03-G8 to the L-peptides 
Family 1

R01-D1 ggagctcagccttcactgc............. CAAG.GTGGGGT.GGTTGGTT.GGA. TTTGGCGGCGAACGGCG......ggCaccacggtcggatcCaC R01-B6 ggagctcagccttcactgc.............GTA..GTGGGGTGGGTTGTT.GGA. TACCCAGTGCGGGCCG......ggcaccacggtcggatccac R01-E3 ggagctcagccttcactgc..............AATT.GTGGGGTTGGCTGGTT.GGA.AATTGCAGTGGACGTCG......ggcaccacggtcggatccac

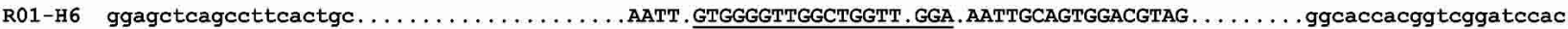
R01-F1 ggagctcagccttcactgc.............. CAC. GTGGGGTTGGTTGGAT.GGA.GTGGTTATGAAAGCCTG.......ggcaccacggtcggatcCac

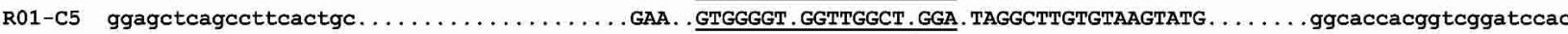
R01-B4 ggagctcagccttcactge................ ATGCGGTGGGGA.GGTTGGAT.GGA. CGCATGCCGGAGGGGTA.......ggcaccacggtcggatccac R01-B1 ggagetcagccttcactgc................TCGA. GTGGGGA. GGTTGGTC. GGA. TTGAGTGTGAGGGGGTTG.......ggcaccacggtcggatccac

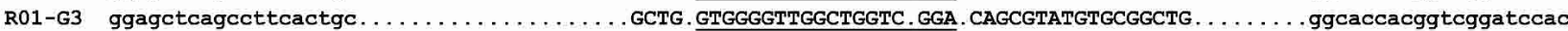
R01-C3 ggagctcagccttcactgc................GT. GTGGGGTTGGATGGTTAGGAACTGCTGTGGGACGGTTG....... ggcacCacggtcggatccac

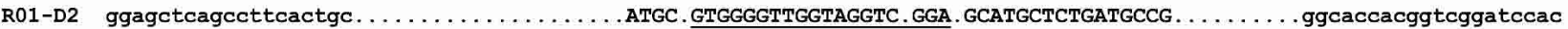

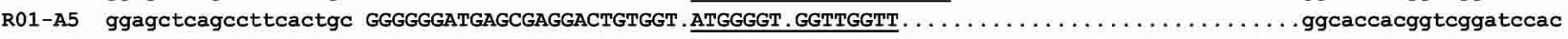

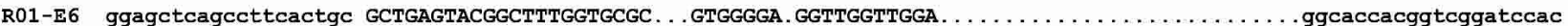
R02-C1 ggagctcagccttcactgc............... TTCCGGTGGGGT.GGTTGGTTGGA. CGGAAGCTGCGAGTTTG........ggcaccacggtcggatccac

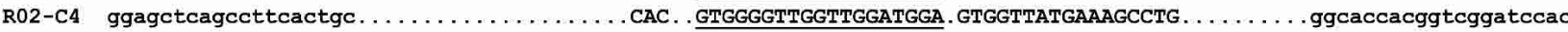
R02-F2 ggagetcagccttcactgc............... TGTAAGTGGGGA.GGTTGGTTGGA. TTGCATCAGAGACGGCT ........ggcaccacggtcggatccac R02-E2 ggagctcagccttcactgc..............ATGCGGTGGGGA.GGTTGGATGGA.CGCATGCCGGAGGGTA.......ggcaccacggtcggatccac

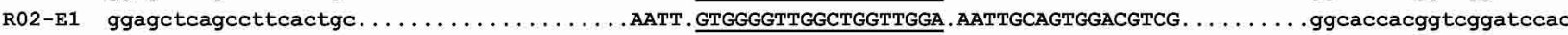
R02-D5 ggagctcagccttcactge............... TCGA.GTGAGGT. GGCTGGTTGGA. TCGAGCGAAGGTTG..........ggcacCacggtcggatccac R03-F7 gggcgetaagtcctcgctca......... CCGTGTCACAATAGGCGTGGGGT. GGTTGGTTGGAGCCCTTTGTGGCGCGATGCGTGTTTG. . aCgCgCgactCggatcctac R03-A7 gggcgctaagtcct gctca. . . . . . . TCGTGTCACAATAGGCGTGGGGT. GGTTGGTTGGAGCCCTTTGTGGCGCGATGCGTGTTTG. . acgcgCgactcggatcctac R03-B11 gggcgctaagtcctcgctca . . . . . . . CCGTGTCACAATAGGCGTGGGGT . GGTTGGTTGGAGCCCTTTGTGGCGCGATGCGTGTTGG. . acgCgCgactcggatcCtac R03-F10 gggcgctaagtcctcgctca. . . . . . . CCGTGTCACAATAGGCGTGGGGT. GGTTGGTTGGAGCCCTTTGTGG GCGATGCGTGTTTG. .acgcgcgactcggatcctac R03-B10 gggcgctaagtcctcgctca....... TGGGAAACGCATGCCAAGTGGGGA. GGTTGGTTGGATTGGTATGATCGCTTCTCCCGTGA. . . acgCgCgactCggatcctaC R03-H10 gggcgctaagtcctcgctca. . . . . . TGGTGAAACGCATGCCAAGTGGGGA. GGTTGGTTGGATTGGTATGATCGTTTCTCCCGTGA. . . acgcgCgactcggatcctac R03-F9 gggcgctaagtcctcgetca. . . . . TTGAAGCTAGGTCAGAGGTGGGG. GGTTGGTTGGACTCTGCCGCTCCTTCGATGGTGAGC. . acgcgCgactcggatcCtac R03-H7 gggcgctaagtcctcgetca. . . . . . TTGAAGCTAGGTCAGAGGTGGGGA. GGTTGGTTGGACTCTGCCGATCTTTGATGGTGAGC. . . acgCgCgactcggatcctac R03-H12 gggcgctaagtcctcgctca......... AAGCTGAAGTACGTGGGTGGGGA. GGTTGGTTGGACCATGAACTTCTCCGCGTAGGGAGG. . acgcgcgactcggatcctac R03-D11 gggcgctaagtcctcgctca. . . . . . . TCAGCCGTGTTAGGAGGTGGGGTTGGTTGGTTGGACTCCTTACATGATGTTGGGCGTCG. . . acgCgCgactcggatcCtaC R03-B9 gggcgctaagtcctcgctca . . . . . . . CATGGAGGGACAGACGTGGGGTTGGCTGGTTGGAGTCTGATTCTGCATGGCGGGCGTGGT. . acgcgCgactcggatcctac R03-A8 gggcgctaagtcctcgetca. . . . . . . CATGGAGGGACAGACGTGGGGTTGGCTGGTTGTAGTCTGATTCTGCATGGGCGTGGT. . . . acgCgCgactcggatcctac R03-H9 gggcgctaagtcctcgctca.......... TTGCCTTITITCAGTGGGGA. GGTTGGTIGGATGAAAAGGGCTTTGAGAGGACC...... acgcgcgactcggatcctac R03-E7 gggcgctaagtcctcgetca. . . . . . . . GTGTGTGACTAAGCCGTGGGGC. GGTTGGATGGAGGCAAGTCCACGCTGTGCGATGGCCGG. acgcgCgactcggatcctaC R03-F11 gggcgctaagtcctcgctca..........GCGTGTGACTAAGCCGTGGGGA. GGTTGGATGGAGGCAAGTCCACGCTGTGCGATGGCCGG acgcgcgactcggatcctac

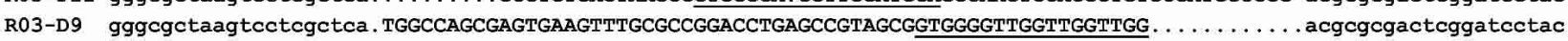
R03-G10 gggcgctaagtcctcgctca. TGCAGTGGGTGCGGGCGGAAGCGAAAGTCTTGAGTTGTGCGGTGGGGAGGTTGGTTGG............acgcgcgactcggatcctac

Family 2

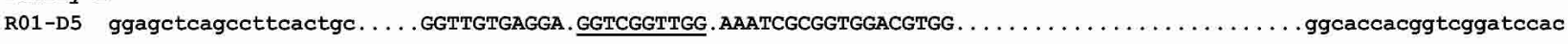
R01-G2 ggagctcagccttcactgc. . . GGTTGTGAGGA.GGTCGGTTGG.ATCGAGCGAAGGTTG. . . . . . . . . . . . . . ggcaccacggtcggatccac

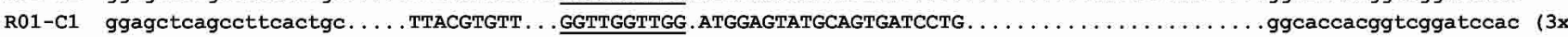

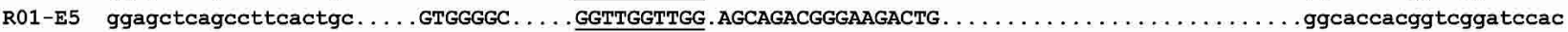
R01-H1 ggagctcagccttcactge. ... CTTGGGGA... GGTTGGTTGG. CGGCAGTGCAAGGCAGCGTGA............... ggcaccacggtcggatccac R03-A10 gggcgctaagtcctcgctca. . . TAGGGTATGGTGG. TGGTTGG. ACTGTCCTGGAAGGATGGGTGAATGCTATGAGAGACGTG. . . . acgcgcgactcggatcctac R03-G11 gggegetaagtcetcgetca.......... GTGTTGGTTGGTTGG. TTGGATGAGGGAGGCCTTAGGAATCGTGACGGCCTGGGTTCAGG . acgcgCgactcggatcctac

Family 3

R01-B5 ggagctcagccttcactgc......AATTCCG.... TGCACGAGATGCTGAC..........GTGTGTGA.GGGGGT.G.......ggcaccacggtcggatccac

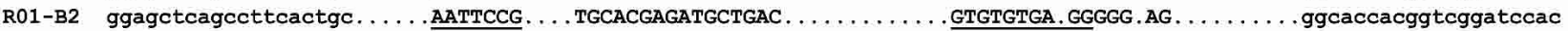

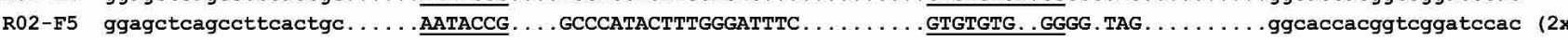
R02-C6 ggagctcagccttcactgc...... AATTCCG. ... GCCCATACTTTGGGATTTC........ GTGTGTG. GGGG.TAG........ggcaccacggtcggatccac

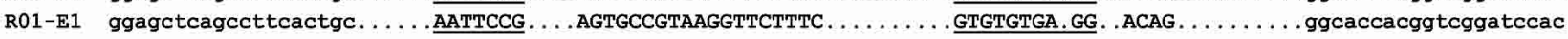
R01-D6 ggagctcagccttcactgc...... AATTCCT .... GCTTTATTACTTAAGTTCA .........GTGTGTGA.GG...TCG........agcaccacggtcggatcCac (2x) R01-E4 ggagctcagcettcactgc..... AATCCCG ....GTAGCGCTGATGCGCTAGGC....... GTGTGTGTTGG.... CG........ggcaccacggtcggatccac

Orphans

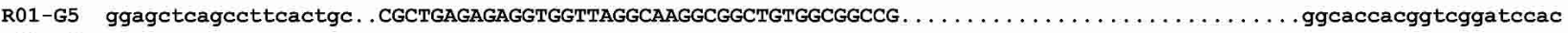
R01-C6 ggagctcagcettcactgc. . TCTGGGAGGGTAGGTTGGGACAAGATGCGGGTGAGGGTAG. . . . . . . . . . . . . . ggcaccacggtcggatccac

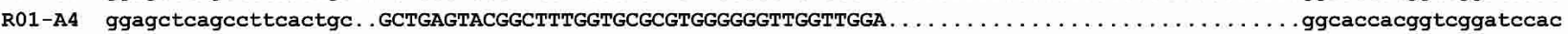

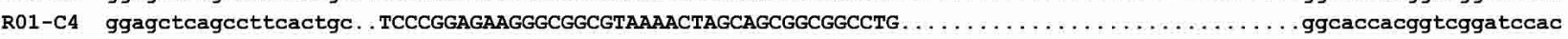

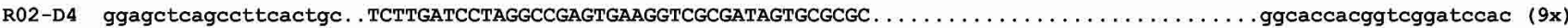

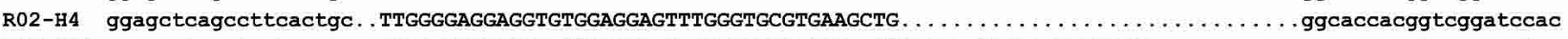
R03-H11 gggcgctaagtcctcgctca.GGGAGCTATGTGCTCGAGCTCATAGCGTGGTAGTGGCTGGTGGAGACAGGAGTGGTGACG............. R03-E12 gggcgctaagtcctcgctca.GTGGGTCCTGGGAGTTACTCAGGTTGACGGTGGTTGGTTTTGGGCTGAGGGATGACCT............ acgCgCgactcggatCctac R03-C10 gggcgctaagtcctcgetca. CACCGCTGTGGGGTGGACGGAGGTGGTGATGTTAAGGGAGGCGAGTGTGATGCTGTGAGG............acgcgCgactcggatcctac R03-G12 gggegctaagtcctcgctca. GAGGCCGGCTGCCCAATTAGCAGTCGGGAAATCAACTAGCGGCTCGGAGCGAGGGTATGG........... acgcgCgactcggatcctac R03-G8 gggcgctaagtcctcgctca.CGACCTCTATATGATACGAGGAGTTTTCTAAAGAACTGGGGGAGTGCCAGTAGGGTGGGG..........acgcgCgactcggatcCtac

FIGURE 1. (Legend on facing page) 
TABLE 1. Observed equilibrium constants of RNA aptamers to free D-N/OFQ.

\begin{tabular}{lcc}
\hline Clone & $\begin{array}{c}\text { Sequence } \\
\text { family }\end{array}$ & $\begin{array}{c}\text { Equilibrium binding } \\
\text { constant } K_{D}(\mu \mathrm{M})^{\mathrm{a}}\end{array}$ \\
\hline R01-B1 & 1 & $1.2 \pm 1.9$ \\
R01-C3 & 1 & $2.7 \pm 3.7$ \\
R02-C4 & 1 & $1.3 \pm 1.6$ \\
R02-D4 & Orphan & $0.3 \pm 0.1$ \\
R03-A12 & 1 & $1.3 \pm 1.3$ \\
R03-A8 & 1 & $1.2 \pm 0.8$ \\
R03-G10 & 1 & $2.1 \pm 2.0$ \\
R03-G8 & Orphan & $0.2 \pm 0.1$ \\
R03-H7 & 1 & $0.7 \pm 0.4$ \\
\hline
\end{tabular}

${ }^{a}$ Screening of isolated aptamers was carried out using fluorescence polarization. Data points were taken at $3,1,0.3,0.1$, and $0 \mu \mathrm{M}$ concentration of RNA aptamer; concentration of fluorescein-labeled D-N/OFQ was $100 \mathrm{nM}$.

was not detectable in the concentration range employed $\left(K_{d}>100 \mu \mathrm{M}\right)$.

Ligand R03-G8 was chosen for further analysis because it showed the highest affinity to free N/OFQ. Truncation and optimization of an aptamer to a minimal binding motif is desirable to allow an easier and cost-effective chemical synthesis. R03-G8 was isolated from the N60 pool and consisted of $100 \mathrm{nt}$. According to the algorithm of the folding program RNAfold (Hofacker et al. 1994), the aptamer forms a clover-leaf-like structure (Fig. 2A) consisting of a stem and two hairpin loops (I and III) that are connected via a bulge of $13 \mathrm{nt}$. The predicted structure was in accordance with results from enzymatic probing experiments (data not shown; Ehresmann et al. 1987).

A minimal binding motif was identified by using base substitutions and deletions and was additionally aided by a reselection using a doped pool of R03-G8. At first, truncations at the $3^{\prime}$ and $5^{\prime}$ termini resulted in the 75 mer ligand NOX 2035 (positions 9-83 of R03-G8, C[9] substituted by $\mathrm{G}$ ) that bound with an affinity of $5.6 \mu \mathrm{M}$ (Table 2). A series of deletions of four bases at a time pinpointed regions that were essential for target binding. When positions $\mathrm{A}(29)$ $\mathrm{U}(32)$ or $\mathrm{G}(33)-\mathrm{A}(36)$ in loop I were deleted (Fig. 2A), binding was still detectable. This was a clear indication that the predicted loop I was not involved in target recognition. Binding was also observed when, in loop II, bases between positions $\mathrm{A}(42)$ and $\mathrm{A}(54)$ were deleted whereas deletions in loop III led to a loss of binding.

When loop $\mathrm{U}(28)-C(37)$ was replaced by a stable GUGA hairpin loop (Antao et al. 1991), the resulting ligand NOX
2053 displayed an affinity of $1.3 \mu \mathrm{M}$. A combination of modifications of NOX 2035 and NOX 2053 led to the 69 mer NOX 2093 that showed an improved $K_{D}$ of $1.8 \mu \mathrm{M}$ compared to NOX 2035. By substituting $C(13)$ to $G(16)$ with $5^{\prime}$-GGAC- $3^{\prime}$ and $U(76)$ to G(79) with $5^{\prime}$-GUCC- ${ }^{\prime}$, we were able to further truncate and stabilize the closing stem to $7 \mathrm{bp}$. This process reduced the size to $61 \mathrm{nt}$, yielding NOX 2124, which displayed a $K_{D}$ of $1.4 \mu \mathrm{M}$.

The goal of the reselection experiment was to identify base positions that were either highly conserved and therefore essential for target binding or less conserved and hence could be substituted by other bases or deleted without losing or even improving target binding affinity. Reselection employed a $15 \%$ doped pool of the ligand R03-G8. As a result of the low mutation rate, variants that contained a few point mutations or deletions were isolated after four and five rounds of selection (sequence data not shown). After five rounds $\sim 17 \%$ of the sequences corresponded to R03-G8. Most mutations were found in loop I, confirming that this region was not directly involved in target binding. Common to most isolated variations was a substitution of $\mathrm{G}(62)$ by any of the other three bases, although substitution by $\mathrm{U}$ was favored. Point mutation $\mathrm{G}(62) \mathrm{U}$, which resulted in NOX 2149 (Fig. 2B), had a significant impact on the affinity to D-N/OFQ, which was determined to a $K_{D}$ of 300 $\mathrm{nM}$. This improvement might be the result of a higher structural stability in NOX 2149. ITC measurements revealed a significantly higher fraction of active binding sequences compared to the other variants, which is consistent with the improvement in activity.

Another strategy employed to identify minimal binding ligands to N/OFQ was to divide R03-G8 into two interdependent fragments (Fig. 2C). The approach was to split the original ligand at sites with relatively large helical regions so that the two fragments could hybridize with each other and yield a binding ligand with the correct three-dimensional structure. Preferred cleavage sites were hairpin loops. In preliminary experiments, cleavages in loops I, II, and III were tested. Interestingly, fragments $\mathrm{G}(1)-\mathrm{U}(47)$ and $\mathrm{C}(48)-\mathrm{C}(100)$ formed a ligand that bound the target at 2.3 $\mu \mathrm{M}$, indicating that loop II may presumably form a third hairpin. However, efforts to further truncate or stabilize these fragments were not successful. The best results were obtained following cleavage in loop I. The hairpin stem was further extended by $4 \mathrm{bp}$ to form a stable closing helix. Fragments of aptamer NOX 2149 were generated and the resulting ligand NOX 2137a/b was reconstituted from 19and $46 \mathrm{mer}$ fragments. The determined binding affinity is $600 \mathrm{nM}$ (Table 2).

FIGURE 1. Sequences of isolated RNA ligands to D-N/OFQ. One-hundred-ninety clones from different selections were sequenced. All of them displayed a high G content. Only those clones that had a measurable affinity to free D-N/OFQ (Table 1) are shown in the figure. N40 and N60 regions are in capital letters, bases belonging to a primer binding site are in small letters, the consensus motif in families 1,2, and 3 is underlined. Numbers in brackets reveal the number of clones related to each of the displayed families. Aptamer R03-G8 appeared only once, and its sequence was not related to any other sequence. 
A

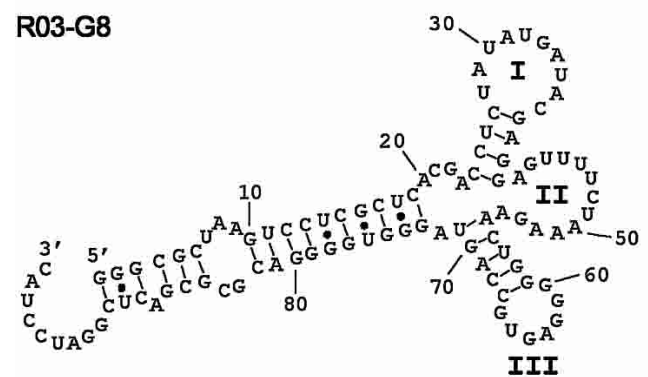

B

NOX 2149

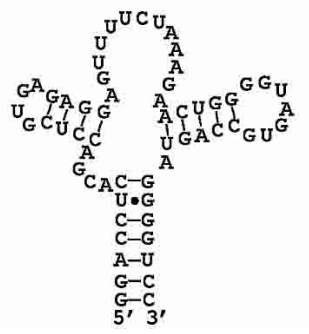

C

NOX 2137a/b

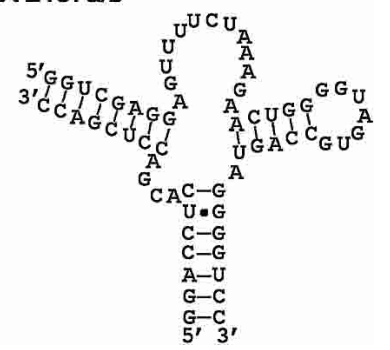

FIGURE 2. Secondary structure models of aptamer R03-G8 (A) and NOX $2149(B)$ and NOX 2137a/b $(C)$. Secondary structure models were generated using RNAfold (Hofacker et al. 1994) and corresponded well with the results of enzymatic probing experiments (Ehresmann et al. 1987). The secondary structures consist of a stem, two hairpin loops, and a 13-nt bulge forming a clover-leaf-like structure. The bulge formed by $A(20) C(21) G(22) A(23)$ opposite the single $A(72)$ in the core of the structure and the hairpin loop $A(50)-U(71)$ seem to be essential for N/OFQ binding.

Aptamers NOX 2149 and NOX 2137a/b were chosen for bioactivity studies and synthesized in their enantiomeric forms. As expected, the Spiegelmer/L-N/OFQ complexes matched the equilibrium binding constants of the aptamer/ D-N/OFQ complexes, within experimental error (Table 2).

\section{In vitro characterization of Spiegelmers that bind N/OFQ}

The interference of the Spiegelmers with the binding of N/OFQ to the ORL1 receptor was shown in a binding competition assay using $\left[{ }^{3} \mathrm{H}\right]-\mathrm{N} / \mathrm{OFQ}$ and the human ORL1

TABLE 2. Observed equilibrium constants of truncated R03-G8 aptamers and Spiegelmers to free D- and L-N/OFQ, respectively

\begin{tabular}{|c|c|c|c|}
\hline \multirow[b]{2}{*}{ Aptamer/Spiegelmer } & \multirow{2}{*}{$\begin{array}{l}\text { Length } \\
\text { (nt) }\end{array}$} & \multicolumn{2}{|c|}{$\begin{array}{l}\text { Equilibrium binding constant } \\
\qquad K_{D}(\mu \mathrm{M})^{\mathrm{a}}\end{array}$} \\
\hline & & FP & $\mathrm{ITC}^{\mathrm{b}}$ \\
\hline N60 pool & 100 & n.d. & \\
\hline R03-G8 & 100 & $0.2 \pm 0.1$ & \\
\hline R03-G3 + L-Noc ${ }^{c}$ & 100 & n.d. & \\
\hline NOX 2035 & 75 & $5.6 \pm 3.0$ & \\
\hline NOX 2053 & 94 & $1.3 \pm 0.5$ & \\
\hline NOX 2124 & 61 & $1.4 \pm 0.4$ & $1.0(0.3)$ \\
\hline NOX 2149 & 61 & $0.3 \pm 0.1$ & $0.2(0.8)$ \\
\hline L-NOX $2149+$ L-Noc $^{C}$ & 61 & $0.3 \pm 0.1$ & $0.2(0.8)$ \\
\hline NOX 2149scr & 61 & n.d. & \\
\hline NOX 2137a/b & $19 / 46$ & $0.6 \pm 0.3$ & $0.6(0.9)$ \\
\hline L-NOX 2137a/b + L-Noc ${ }^{c}$ & $19 / 46$ & $0.7 \pm 0.4$ & $0.6(0.9)$ \\
\hline \multicolumn{4}{|c|}{$\begin{array}{l}\text { aEquilibrium binding constants were determined using fluores- } \\
\text { cence polarization (FP) and isothermal titration calorimetry (ITC). } \\
\text { With fluorescence polarization, } 10 \text { data points in a concentration } \\
\text { range of } 0.001-50 \mu \mathrm{M} \text { RNA aptamer were taken; concentration of } \\
\text { fluorescein-labeled D-N/OFQ or L-N/OFQ was } 100 \mathrm{nM} \text {. Measure- } \\
\text { ments were carried out in duplicate. } \\
{ }^{b} K_{D} \text { values are with respect to total RNA concentration, numbers in } \\
\text { parentheses refer to the portions of molecules in active, binding } \\
\text { conformations. } \\
{ }^{c} \text { Affinity to L-N/OFQ was determined. } \\
\text { n.d., not detectable. }\end{array}$} \\
\hline
\end{tabular}

receptor. Spiegelmers NOX 2149 and NOX 2137a/b inhibited $\left[{ }^{3} \mathrm{H}\right]-\mathrm{N} / \mathrm{OFQ}$ binding, yielding a classical sigmoidal dose response curve. The calculated $\mathrm{IC}_{50}$ values were 300 $\mathrm{nM}$ for NOX 2137a/b and $110 \mathrm{nM}$ for NOX 2149 (Fig. 3). In this experimental setting, the control Spiegelmer NOX 2149 scr inhibited ${ }^{3} \mathrm{H}-\mathrm{N} / \mathrm{OFQ}$ binding to ORL1 by $~ 50 \%$ at the highest tested concentration of $10 \mu \mathrm{M}$. However, the specific effects are clear and significant and the results are in good agreement with the biophysically determined binding affinities of NOX 2149 and NOX 2137a/b to N/OFQ.

For further characterization, the Spiegelmers were analyzed in a functional GTP $\gamma \mathrm{S}$ assay. Consistent with the binding characteristics described above, both Spiegelmers antagonized N/OFQ-induced $\left[{ }^{35} \mathrm{~S}\right] \mathrm{GTP} \gamma \mathrm{S}$ incorporation into membranes containing the human ORL1 receptor (Fig. $4 \mathrm{~A})$. In the presence of $1 \mu \mathrm{M}$ Spiegelmer, the dose-response curve of N/OFQ showed a rightward shift. In this assay, the Spiegelmers behave like competitive antagonists with the

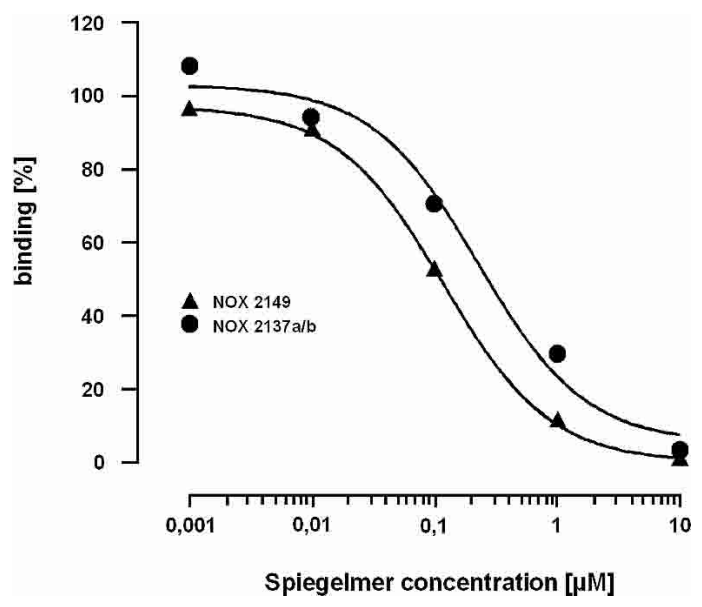

FIGURE 3. Competition binding for $\left[{ }^{3} \mathrm{H}\right]$-labeled N/OFQ between the expressed ORL1 receptor in $\mathrm{CHO}$ cells and various concentrations of the N/OFQ-Spiegelmer NOX 2149 (filled diamond) and NOX $2137 \mathrm{a} / \mathrm{b}$ (filled circle). (Binding assay was carried out as described in Materials and Methods.) 
A

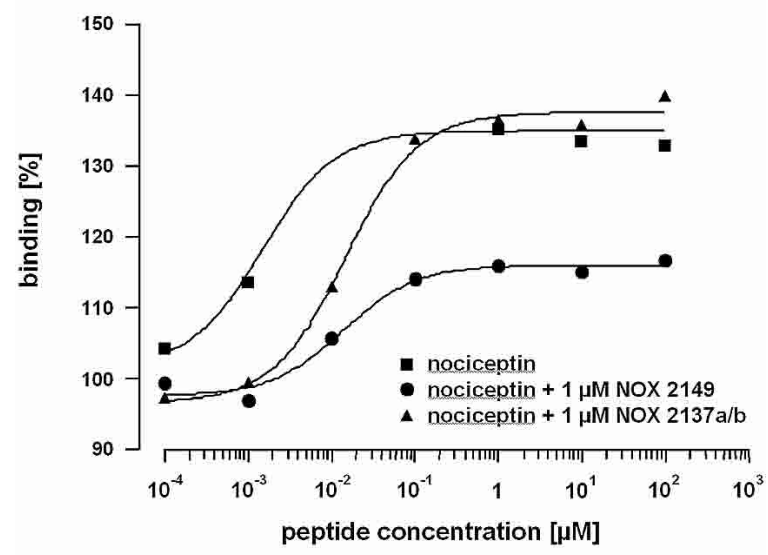

B

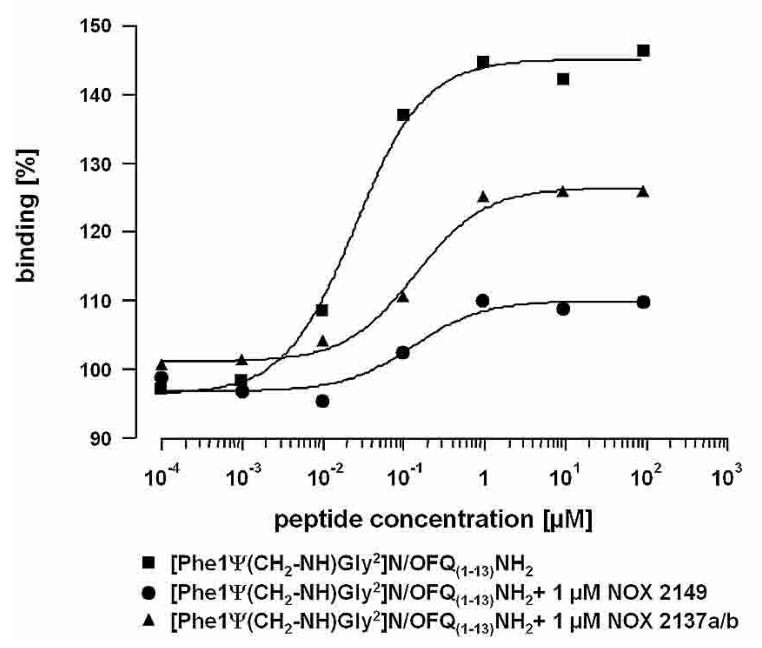

FIGURE 4. Analysis of Spiegelmers in a functional GTP $\gamma \mathrm{S}$-assay. $\mathrm{N} / \mathrm{OFQ}(A)$ or $\left[\mathrm{Phe}^{1} \psi\left(\mathrm{CH}_{2}-\mathrm{NH}\right) \mathrm{Gly}^{2}\right] \mathrm{N} / \mathrm{OFQ}_{(1-13)} \mathrm{NH}_{2}(B)$ induces $\left[{ }^{35} \mathrm{~S}\right] \mathrm{GTP} \gamma \mathrm{S}$ binding to membranes of $\mathrm{CHO}$ cells stably expressing the human ORL1 receptor. The membranes were incubated with 0.4 nmole $\left[{ }^{35} \mathrm{~S}\right] \mathrm{GTP} \gamma \mathrm{S}$ and $10 \mu \mathrm{mole} / \mathrm{L}$ GDP and various concentrations of the agonists. To show functional antagonism of the Spiegelmers, the reaction was also carried out in the presence of $1 \mu \mathrm{M}$ NOX $2137 \mathrm{a} / \mathrm{b}$ or $1 \mu \mathrm{M}$ NOX 2149. The data shown present mean values expressed as percent stimulation of $\left[{ }^{35} \mathrm{~S}\right] \mathrm{GTP} \gamma \mathrm{S}$ binding with basal $\left[{ }^{35} \mathrm{~S}\right] \mathrm{GTP} \gamma \mathrm{S}$ bound set at $100 \%$.

receptor and Spiegelmer competing for binding of the neuropeptide N/OFQ. Furthermore, the Spiegelmer NOX 2149 reduced the maximal binding of N/OFQ in this assay. Additional experiments were performed to evaluate the selectivity of the Spiegelmer effect. The pseudo-peptide $\left[\mathrm{Phe}^{1} \psi\left(\mathrm{CH}_{2}-\mathrm{NH}\right) \mathrm{Gly}^{2}\right] \mathrm{N} / \mathrm{OFQ}_{(1-13)} \mathrm{NH}_{2}$ has been described as a partial ORL1 agonist (Guerrini et al. 1998; Burnside et al. 2000). Its pseudo-peptide bond differs from natural peptide bonds by a methylene group at the $\alpha$-carbon atom of the amino-terminal phenylalanine derivative instead of a carbonyl function. Interestingly, the $\left[\mathrm{Phe}^{1} \psi\left(\mathrm{CH}_{2}-\mathrm{NH}\right) \mathrm{Gly}^{2}\right] \mathrm{N} / \mathrm{OFQ}_{(1-13)} \mathrm{NH}_{2}$ induced $\left[{ }^{35} \mathrm{~S}\right] \mathrm{GTP} \gamma \mathrm{S}$ binding, which was antagonized by both Spiegelmers (Fig. 4B). This clearly indicates that both Spiegelmers do not bind to the N terminus of N/OFQ. GRT2932Q, a nonpeptidic ORL1 agonist induced $\left[{ }^{35} \mathrm{~S}\right] \mathrm{GTP} \gamma \mathrm{S}$ incorporation that was not antagonized by either Spiegelmer (data not shown).

In a GTP $\gamma S$ assay using human $\mu$-opioid receptor, the Spiegelmers were tested against various opioid ligands. The agonists morphine, DAMGO, endomorphin-1, and endomorphin-2 all induced GTP $\gamma$ S incorporation, but were unaffected by the addition of $1 \mu \mathrm{M}$ Spiegelmer. Results of the GTP $\gamma \mathrm{S}$ assays are summarized in Table 3.

The Spiegelmers showed also a clear effect on the N/OFQ-ORL1 receptor system in oocytes from Xenopus laevis. The ORL1 receptor is functionally coupled with Gprotein-regulated inwardly rectifying $\mathrm{K}^{+}$channels (GIRK) in excitable cells and can also be expressed in oocytes from X. laevis (Ikeda et al. 1997). ORL1 was coexpressed with GIRK1 for the study of the interaction of NOX 2149 and N/OFQ. Because the inward rectifier passes a larger current in the inward than in the outward direction, the currents were measured for accuracy at negative potentials in oocytes previously depolarized by $98 \mathrm{mM}$ external $\mathrm{K}^{+}$concentration.

In ORL1-GIRK1-cRNA-injected oocytes, N/OFQ produced a pronounced inward current that rapidly increased to a peak current and then slowly inactivated to nearly $30 \%$ of the maximum effect (Fig. 5A). The average N/OFQ-induced peak current was $-318 \mathrm{nA}$ compared to $-135 \mathrm{nA}$ for the noninduced control (Fig. 5B). NOX 2149 reduced the effect of N/OFQ on the peak current by about $50 \%$ when added after N/OFQ (Fig. 5C). The inhibitory effect was also seen when Spiegelmer NOX 2149 was added first (Fig. 5D). The concentrations of the Spiegelmers $(10 \mu \mathrm{M})$ were 20 times higher than the concentrations of the agonist N/OFQ $(0.5 \mu \mathrm{M})$ used. To show that the inhibitory effect of Spiegelmer NOX 2149 is related to its antagonistic properties and not due to Spiegelmers in general, the sequencescrambled Spiegelmer NOX 2149scr was also tested as a control. As expected, an inhibitory effect of NOX 2149scr was not observed (Fig. 6). This corresponds well with the result of an ITC experiment that also did not show binding of NOX 2149scr to N/OFQ in the concentration range measured (Table 2). The specificity of the Spiegelmer NOX 2149

TABLE 3. Summary of the effect of Spiegelmers in GTP $\gamma$ S-assay

\begin{tabular}{lll}
\hline Ligand & \multicolumn{1}{c}{ Receptor } & $\begin{array}{c}\text { Effect of } \\
\text { Spiegelmer }\end{array}$ \\
\hline $\begin{array}{l}\mathrm{N} / \mathrm{OFQ} \\
{\left[\mathrm{Phe}^{1} \Psi\left(\mathrm{CH}_{2}-\mathrm{NH}\right) \mathrm{Gly}^{2}\right] \mathrm{N} /}\end{array}$ & Human ORL1 & Antagonistic \\
$\mathrm{OFQ}(1-13) \mathrm{NH}_{2}$ & Human ORL1 & Antagonistic \\
GRT2932Q & Human ORL1 & No effect \\
Buprenorphine & Human ORL1 & No effect \\
Morphine & Human $\mu$-opioid & No effect \\
DAMGO & Human $\mu$-opioid & No effect \\
Endomorphin-1 & Human $\mu$-opioid & No effect \\
Endomorphin-2 & Human $\mu$-opioid & No effect \\
\hline
\end{tabular}



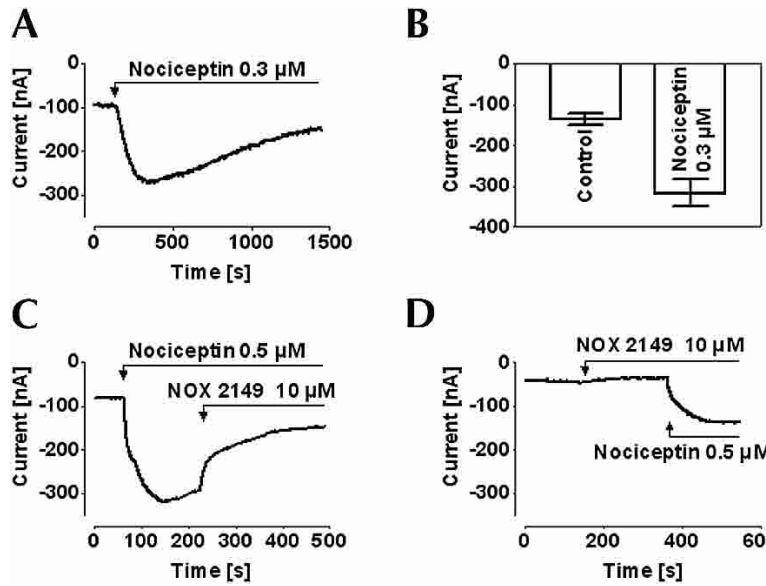

D

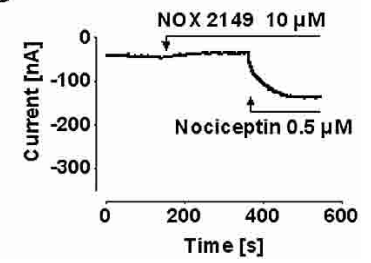

FIGURE 5. Effect of NOX 2149 on N/OFQ on membrane currents in ORL1-GIRK1-cRNA-injected oocytes. $\left[\mathrm{K}^{+}\right]_{0} 96 \mathrm{mM}$; Vc $-60 \mathrm{mV}$. (A) Original current record in control conditions and after the addition of N/OFQ $(0.3 \mu \mathrm{M})$. (B) Control and peak currents after the addition of N/OFQ $(0.3 \mu \mathrm{M})$. Means \pm S.E.M. $(n=36)$. $(C)$ Original current trace in response to N/OFQ and NOX 2149, added consecutively. (D) Original current trace in response to NOX 2149 and N/OFQ, consecutively.

was also tested with buprenorphine. The effects of buprenorphine, which also activates ORL1 receptors (BlomsFunke et al. 2000), remained unchanged in the presence of NOX 2149 (Fig. 6). This further emphasizes the specificity of NOX 2149 for N/OFQ.

\section{DISCUSSION}

\section{In vitro selection and biophysical characterization of RNA ligands to N/OFQ}

In recent years, a great number of nucleic acid ligands recognizing a wide range of different target molecules (Jayasena 1999; Brody and Gold 2000; Toulmé 2000) have been identified by in vitro selection and evolution of combinatorial nucleic acid libraries. Targets have included small molecules such as theophylline or cyanocobalamine as well as large molecules such as proteins. The affinities and specificities of the described aptamers often rival those of antibodies. However, nucleic acid ligands have long been hampered by their comparatively low stability in a biological environment. Even extensive postselection modifications of aptamers were not able to resolve the stability problem. An elegant solution to this obstacle is presented by Spiegelmers, which are not recognized by mammalian nucleases and are, therefore, highly stable in vivo. The goal of this work was to apply the Spiegelmer technology to identify biostable nucleic acid ligands that recognize the neuropeptide N/OFQ with high affinity and specificity and to assess their biological function in vitro. In the course of the selection process, a number of high affinity ligands were successfully isolated. The selection under more stringent conditions in later rounds led to a depletion of sequence variety as expected. The binding affinities were in the range from $200 \mathrm{nM}$ to 3 $\mu \mathrm{M}$ as determined by fluorescence polarization. Nucleic acid ligand R03-G8 was chosen for further characterization and optimization because of its favorable high binding affinity $\left(K_{D}\right.$ of $\left.200 \mathrm{nM}\right)$ to N/OFQ.

Some of the ligands that bound to immobilized N/OFQ failed to recognize the free target. This is probably due to their individual binding sites. A general obstacle in the selection against a small target molecule is that the immobilization linker occasionally represents a part of the recognition site of the ligand. This seemed to be the case in a number of the selected nucleic acid ligands described in this work. A possible solution to this problem could be the use of linkers that offer far fewer interaction possibilities with nucleic acid ligands than amino acid analogs such as alkoxyethylene glycols.

The Spiegelmers described in this work compare well with other nucleic acid ligands reported in literature, for example aptamers that bind substance P (Nieuwlandt et al. 1995), a hexadecapeptide corresponding to the argininerich motif of HIV-1 Rev (Xu and Ellington 1996), and Spiegelmers that bind the constrained Vasopressin (Williams et al. 1997 and the nonconstrained GnRH (Leva et al. 2002). The binding constants to these peptides are in the low nanomolar to micromolar range.

Upon complex formation, an aptamer generally has two possibilities to react with the conformation of the target molecule; either it undergoes structural rearrangement to adapt to the target conformation, as described for aptamers binding the MS2 coat protein (Convery et al. 1998; Rowsell et al. 1998), or it dictates the conformation of the bound target, as previously described for complexes of the arginine-rich motif of HIV-1 Rev and two different RNA mol-

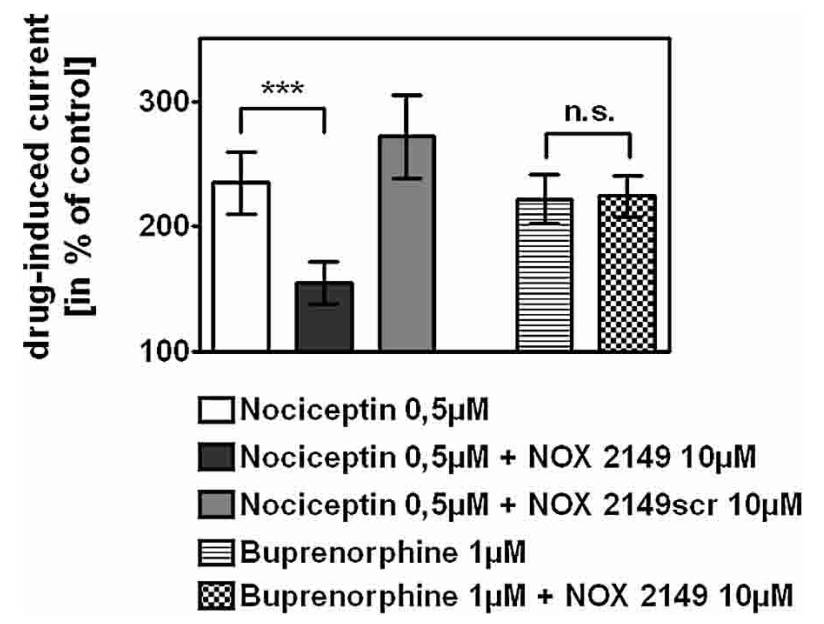

FIGURE 6. The response of N/OFQ $(n=24)$, the effects of NOX 2149 $(n=18)$, and NOX 2149scr $(n=6)$ on the responses to N/OFQ, as well as the response of buprenorphine $(n=3)$ and the effect of NOX 2149 on the responses to buprenorphine $(n=3)$. Means \pm S.E.M. ${ }^{* *} p ; 0.001$. 
ecules (Ye et al. 1999). N/OFQ is a nonconstrained heptadecapeptide with a sequence very similar to dynorphin A, but its conformational state in solution is less ordered (Salvadori et al. 1997). Because the conformation of N/OFQ is relatively disordered, the second mechanism of action is more likely to apply here. An aptamer or Spiegelmer must itself be rather rigid and well defined to fix the flexible, nonconstrained N/OFQ into a specific conformation. As a consequence, the search for a size-minimized Spiegelmer had to result from truncation experiments accompanied by attempts to stabilize the secondary and tertiary structure of the Spiegelmer. Such structural stabilization can be achieved through minor changes in the primary structure of a nucleic acid ligand. This was clearly demonstrated in this work by the single point mutation G(62)U from NOX 2124 to NOX 2149. ITC measurements revealed significant differences in the activity of these ligands. Although the binding affinities for the active conformation of these two Spiegelmers were similar, the percentages of functional molecules were $30 \%$ and $80 \%$, respectively. This resulted in a significantly improved overall $K_{D}$ of NOX 2149 (Table 2). Moreover, this was observed by fluorescence polarization, where the observed $K_{D}$ is a result of the average effects of active and inactive binding conformations of the nucleic acid ligand.

An optimization of the Spiegelmer by size minimization is necessary, because it will lead to more efficient chemical synthesis and effectively reduces the cost of a potential therapeutic substance. Partial truncation of the $5^{\prime}$ and $3^{\prime}$ primer to a 75mer (NOX 2035) resulted in a binding affinity of $5.6 \mu \mathrm{M}$, a loss in binding affinity of $\sim 30$-fold. However, substitution of the 10-nt loop of hairpin I by a rigid GUGA tetraloop not only further reduced the Spiegelmer size, but also improved the binding affinity $\sim 6$-fold to a $K_{D}$ of $1 \mu \mathrm{M}$. A further optimization targeting the closing stem of the Spiegelmer by sequence mutation and truncation resulted in a $61 \mathrm{mer}$ with a $K_{D}$ of $1.4 \mu \mathrm{M}$. A point mutation in the loop of hairpin III improved the binding affinity to a $K_{D}$ of $300 \mathrm{nM}$. As a result of the size minimization, the reduction of the length of the Spiegelmer by more than 40 nucleobases was achieved with next to no loss in binding affinity to N/OFQ.

The reconstitution of a nucleic acid ligand from two independent fragments was found to be an efficient alternative to obtain a minimal binding motif. It allows the generation of relatively long Spiegelmers in a large-scale synthesis with acceptable efficiency and costs. Affinity and bioactivity of the resulting Spiegelmer L-NOX 2137a/b were comparable to those of L-NOX 2149 in the concentration range used in the different assays. The reconstitution of two independent fragments also allows a closer analysis of the interaction site of ligand and target. Although loop I is readily opened up without losing target recognition, this is not possible in loop III. Therefore, it appears that loop I is not involved in direct ligand-target interaction and that the hairpin is mainly responsible for the proper three-dimensional shape of the Spiegelmer. In contrast, the loop region of hairpin III seems to be closely involved in the ligandtarget recognition.

\section{In vitro characterization of Spiegelmers that bind N/OFQ}

The antagonistic properties of Spiegelmers NOX 2149 and NOX $2137 \mathrm{a} / \mathrm{b}$ were demonstrated in various functional assays. The Spiegelmers were shown to antagonize the effect of N/OFQ in a binding competition assay to the ORL1 receptor. The Spiegelmers also antagonized the N/OFQinduced GTP $\gamma \mathrm{S}$ incorporation into cell membranes of CHO-K1 cells expressing the human ORL1 receptor. Interestingly, both Spiegelmers also antagonized $\left[\mathrm{Phe}^{1} \psi\left(\mathrm{CH}_{2}-\right.\right.$ $\left.\mathrm{NH}) \mathrm{Gly}^{2}\right] \mathrm{N} / \mathrm{OFQ}_{(1-13)} \mathrm{NH}_{2}$, suggesting that the interaction site between nucleic acid ligand and peptide is the middle part of N/OFQ. The high specificity of the Spiegelmers was also demonstrated. NOX 2149 showed neither detectable binding to the high sequence homologous dynorphin $\mathrm{A}$ in an ITC measurement nor to various other opioid ligands in a GTP $\gamma$ S assay (Table 3).

In a second model employing oocytes from X. laevis, NOX 2149 demonstrated an antagonistic effect to the N/OFQ-ORL 1 receptor system that was functionally coupled with G-protein-regulated inwardly rectifying $\mathrm{K}^{+}$ channels. The Spiegelmer inhibited the effect of N/OFQ by about $50 \%$ of the induced peak current. This was observed whether the Spiegelmer was added to the oocytes prior to or after N/OFQ. No effect was observed in control experiments with Spiegelmer NOX 2149scr or buprenorphine. These results further emphasize the excellent antagonistic properties and specificity of NOX 2149 and NOX 2137a/b for N/OFQ.

Nucleic acid ligands are beginning to emerge as a class of molecules that rival antibodies in both therapeutic and diagnostic applications. This is true not only for aptamers, but especially for Spiegelmers, principally because of their enhanced stability. The RNA Spiegelmers identified in our work recognize the neuropeptide N/OFQ and are efficient inhibitors of its effects, as was shown in three model systems. They add to previously described Spiegelmers that bind adenosine (Klussmann et al. 1996) and arginine (Nolte et al. 1996), vasopressin (Williams et al. 1997) and GnRH (Leva et al. 2002). Given the fact that Spiegelmers combine the excellent binding properties of aptamers and show remarkable stability in serum and other biological fluids, they are considered superior to D-nucleic acid aptamers whose stability must be improved by sometimes cumbersome and lengthy postselective modification processes. The development of Spiegelmer diagnostics or therapeutics also benefits from the high degree of nuclease resistance of this substance class and the established production methods available for oligonucleotides. 


\section{MATERIALS AND METHODS}

\section{Materials}

L-N/OFQ (FGGFTGARKSARKLANQ) was purchased from Bachem and Neosystem Laboratoire. ORL1 agonist $\mathrm{N} / \mathrm{OFQ}_{(1-13)} \mathrm{NH}_{2}$ and the partial agonist $\left[\mathrm{Phe}^{1} \psi\left(\mathrm{CH}_{2}-\mathrm{NH}\right) \mathrm{Gly}^{2}\right] \mathrm{N} / \mathrm{OFQ}_{(1-13)} \mathrm{NH}_{2}$ as well as endomorphin-1 and endomorphin-2 were purchased from Neosystem Laboratoire. D-N/OFQ and fluorescein-labeled D- and L-N/OFQ were custom synthesized by Jerini BioTools with a spacer ( $\beta$-Ala- $\beta$-Ala) between fluorescein and N/OFQ. [leucyl$\left.{ }^{3} \mathrm{H}\right]-\mathrm{N} / \mathrm{OFQ}$ was purchased from Amersham Pharmacia Biotech. Synthetic DNA pools containing $40 \mathrm{nt}$ and $60 \mathrm{nt}$ completely randomized sequence tracts were custom synthesized by Metabion. All other synthetic DNA and RNA oligomers were synthesized by NOXXON Pharma AG using standard oligonucleotide synthesis procedures on an ABI 394 Nucleic Acid Synthesizer (Applied Biosystems). L-Phosphoramidites were synthesized by NOXXON Pharma AG. RNA Spiegelmers NOX 2137a, NOX 2137b, NOX 2149 , and the sequence-scrambled Spiegelmer NOX 2149scr allotted to biological assays were synthesized on an ÄKTA oligopilot 10 (Amersham Pharmacia Biotech) using standard $\beta$-cyanoethyl chemistry, and purified by polyacrylamide gel electrophoresis or reversed-phase HPLC. Cloning and sequencing of enriched pools was performed by Agowa. Radionucleotides were purchased from Hartmann Analytic. Superscript II reverse transcriptase, Taq DNA polymerase, RNase inhibitor (RNase OUT), and T4 RNA ligase were purchased from Life Technologies, and T7 RNA polymerase from Stratagene. DAMGO and buprenorphine were obtained from Research Biochemicals Inc. (RS)-8-acenaphten-1-yl-1-phenyl-1,3,8-triazaspiro[4.5]-decan-4-one hydrochloride (GRT2932Q) was synthesized at Grünenthal GmbH (Rover et al. 2000a, 2000b). Collagenase A was obtained from Roche. All other chemicals used were purchased from Sigma.

\section{Methods}

\section{In vitro selection}

DNA oligonucleotide template libraries 5'-GGAGCTCAGCCTTCACT GC-N $_{40}$-GGCACCACGGTCGGATCCAC-3' (N40) and 5'-GCGCT AAGTCCTCGCTCA-N ${ }_{60}$-ACGCGCGACTCGGATCCTAC-3' (N60), with $\mathrm{N}$ symbolizing an equimolar mixture of $\mathrm{A}, \mathrm{C}, \mathrm{G}$, and $\mathrm{T}$, were prepared by chemical synthesis. Oligonucleotide primers used in reverse transcription and PCR experiments had the following sequences: N40T7, 5' -TCTAATACGACTCACTATAGGAGCTCA GCCTTCACTGC-3'; N40R， 5'-GTGGATCCGACCGTGGTGCC3'; N60T7, 5'-TCTAATACGACTCACTATAGGGCGCTAAGTCCT CGCTCA-3'; and N60R, 5'-GTAGGATCCGAGTCGCGCGT-3'. Double-stranded DNA pools were generated from 5 nmole of synthetic N40 and N60 DNA oligomers. Because not all ssDNA molecules were used as templates by the DNA polymerase (which was determined in a PCR reaction with only one cycle) we calculated that $\sim 20-23 \%$ (corresponding to $7 \times 10^{14}$ and $6 \times 10^{14}$ copyable molecules, respectively) were accessible by large-scale PCR. Amplification was carried out in $50-\mathrm{mL}$ reactions containing $3 \mu \mathrm{M}$ reverse and forward primer, $0.2 \mathrm{mM}$ of each dNTP, $20 \mathrm{mM}$ Tris ( $\mathrm{pH} 8.0$ ), $50 \mathrm{mM}$ $\mathrm{KCl}, 2.5 \mathrm{mM} \mathrm{MgCl}_{2}$, and 50 units/mL Taq DNA polymerase. RNA pools were generated by transcription of DNA pools in $80 \mathrm{mM}$ HEPES (pH 7.4), $22 \mathrm{mM} \mathrm{MgCl}_{2}, 10 \mathrm{mM}$ dithiothreitol, $4 \mathrm{mM}$ of each NTP, $12 \mu \mathrm{g} / \mathrm{mL}$ BSA, 400 units/mL RNase OUT RNase inhibitor, and 1000 units/mL T7 RNA polymerase. Transcribed RNA pools were purified on $10 \%$ polyacrylamide gels containing $7 \mathrm{M}$ urea. RNA was extracted by "crush and soak" in $500 \mathrm{mM}$ ammonium acetate, $1 \mathrm{mM}$ EDTA, and 0.1\% SDS (Sambrook et al. 1989).

In two reactions, 750 nmole and 200 nmole D-N/OFQ were coupled to 5 -mL bed volume of $\mathrm{N}$-hydroxysuccinimide-activated Sepharose 4 fast flow (Amersham Pharmacia Biotech) according to the manufacturer's instructions. The amount of peptide present in solution before and after the derivatization was determined by HPLC. Based on the wet bed volume, the "concentration" of the retained peptide on the affinity resin was calculated to be $100 \mu \mathrm{M}$ and $25 \mu \mathrm{M}$, respectively. A resin for preselection was generated by derivatizing $N$-hydroxysuccinimide-activated Sepharose 4 fast flow with ethanolamine.

The in vitro selection process of affinity selection followed by amplification of the selected pool has been described in detail (Leva et al. 2002). Briefly, RNA was dissolved in selection buffer (10 mM HEPES at $\mathrm{pH} 7.4,150 \mathrm{mM} \mathrm{NaCl}, 5 \mathrm{mM} \mathrm{KCl}, 1 \mathrm{mM}$ $\mathrm{MgCl}_{2}, 2 \mathrm{mM} \mathrm{CaCl}, 0.005 \%$ Triton X-100). Resins for selection and for preselection were equilibrated with 10 column volumes of selection buffer before adding the RNA pool. In the first selection round, $29 \mu \mathrm{g}$ ( $1.1 \mathrm{nmole}) \mathrm{N} 40 \mathrm{RNA}$ pool or $43 \mu \mathrm{g}$ ( $1.3 \mathrm{nmole}) \mathrm{N} 60$ RNA pool in $300 \mu \mathrm{L}$ selection buffer were mixed with $200 \mu \mathrm{L}$ resin derivatized with $100 \mu \mathrm{M}$ D-N/OFQ at $25^{\circ} \mathrm{C}$. The mixture was incubated for $30 \mathrm{~min}$ at $25^{\circ} \mathrm{C}$. Afterward, the resin was washed six times with $200 \mu \mathrm{L}$ selection buffer. For elution of specifically bound RNA, the resin was incubated three times with $200 \mu \mathrm{L}$ selection buffer containing $400 \mu \mathrm{M}$ D-N/OFQ. In the first and third elution steps, the respective flow-through was collected without further incubation. The second elution step was carried out by incubating the resin with the peptide solution for $90 \mathrm{~min}$ in a shaker. RNA was isolated and reverse transcribed. Reverse transcription was followed by eight to 15 cycles of PCR, subsequent transcription, and the resulting RNA was subjected to further cycles of selection. In following cycles, $13 \mu \mathrm{g}$ N40 and $17 \mu \mathrm{g}$ N60 RNA pool (500 pmole each) in $50 \mu \mathrm{L}$ selection buffer were incubated with $50 \mu \mathrm{L}$ resin for preselection for $30 \mathrm{~min}$ to remove RNA species that bind specifically to the resin itself. The preselection resin was washed twice with $50 \mu \mathrm{L}$ selection buffer, and the combined eluates were mixed with $100 \mu \mathrm{L}$ peptide-derivatized resin and incubated as above. Afterward, the resin was washed with 1.9 $\mathrm{mL}$ selection buffer in early rounds and up to $4.0 \mathrm{~mL}$ selection buffer in later rounds. Beginning with round 10, a resin that was derivatized with $25 \mu \mathrm{M}$ D-N/OFQ was used for selection, and specifically bound RNA pool was eluted with $300 \mu \mathrm{L}$ selection buffer containing $400 \mu \mathrm{M}$ D-N/OFQ in three fractions as described above.

For a reselection experiment, the N60 region of sequence R03G8 (Fig. 1) was mutagenized with $15 \%$ efficiency per base position ( $85 \%$ original nucleobase of R03-G8 per position was mixed with $5 \%$ each of the other three nucleobases) and flanked by the primer-binding sites of the N60 RNA pool to yield a doped pool around the original R03-G8 ligand. In the first selection round, 43 $\mu \mathrm{g}$ ( 1.3 nmole) doped RNA pool in $200 \mu \mathrm{L}$ selection buffer and 200 $\mu \mathrm{L}$ of affinity resin derivatized with $100 \mu \mathrm{M}$ D-N/OFQ were used. The resin was washed with $1 \mathrm{~mL}$ selection buffer, and specifically bound pool was eluted with $600 \mu \mathrm{L}$ selection buffer containing 400 
$\mu \mathrm{M} D-\mathrm{N} / \mathrm{OFQ}$ in three fractions. The resin was incubated with the peptide solution for $90 \mathrm{~min}$ in the second and third elution steps. In the second and following cycles of selection and amplification, 500 pmole RNA pool, $50 \mu \mathrm{L}$ resin for preselection, and $100 \mu \mathrm{L}$ affinity resin were used. Five hundred microliters of selection buffer were used for washing. Elution of specifically bound pool was carried out with $300 \mu \mathrm{L}$ peptide solution as described above.

\section{Measurement of binding affinities}

Affinities of RNA to fluorescein-labeled N/OFQ as a tracer peptide were determined by fluorescence polarization. Measurements were performed on a PolarStar Galaxy (BMG Labtechnologies GmbH) at $25^{\circ} \mathrm{C}$. Measurements were made in selection buffer omitting Triton X-100 and replacing HEPES by Tris, or in HBSS (Life Technologies). For measurements, stock solutions of RNA samples were prepared by dissolving the RNA in buffer containing $10 \mathrm{mM}$ Tris (pH 7.4), $150 \mathrm{mM} \mathrm{NaCl}, 5 \mathrm{mM} \mathrm{KCl}, 1 \mathrm{mM} \mathrm{MgCl}_{2}$, and $2 \mathrm{mM}$ $\mathrm{CaCl}_{2}$ or in HBSS. The stock solution was heated for 3 min to $94^{\circ} \mathrm{C}$ and incubated for $15 \mathrm{~min}$ at $25^{\circ} \mathrm{C}$ before a series of dilutions was made from the stock solution in the same buffer. To each sample, tracer peptide was added to a final concentration of $100 \mathrm{nM}$. Final RNA concentrations ranged from $1 \mathrm{nM}$ to $10 \mu \mathrm{M}$. Samples were excited at $485 \mathrm{~nm}$ and fluorescence was monitored at $520 \mathrm{~nm}$. Collected data points were fitted to a 1:1 binding model using least mean squares regression. Binding constants are the mean values from two independent experiments.

Affinities of RNA aptamers and Spiegelmers to free D-N/OFQ and L-N/OFQ, respectively, and the portions of actively binding molecules were determined by isothermal titration calorimetry (ITC) on a MicroCal VP-ITC (MicroCal LLC). Measurements were carried out in degassed selection buffer at $25^{\circ} \mathrm{C}$ with a stirring speed of $300 \mathrm{rpm}$. The measuring cell was loaded with D- or L-RNA. The respective D- or L-N/OFQ solution was injected (one $3-\mu \mathrm{L}$ injection followed by $6-\mu \mathrm{L}$ injections) from a $250-\mathrm{mL}$ syringe over a time interval of $6 \mathrm{sec}$ with $300 \mathrm{sec}$ between each injection to allow complete equilibration and baseline recovery. The concentration of N/OFQ in the syringe was eight times the RNA concentration in each experiment. RNA concentrations were in a range of 7-8 $\mu \mathrm{M}$.

\section{N/OFQ binding to recombinant human ORL1 receptor}

For these studies, membranes from CHO-K1 cells transfected with human ORL1 receptor (Receptor Biology Inc.) were thawed rapidly, diluted 20-fold with assay buffer (50 mM HEPES at $\mathrm{pH} 7.4$, $10 \mathrm{mM} \mathrm{MgCl}, 1 \mathrm{mM}$ EDTA), and resuspended by homogenization. The membrane homogenate was preincubated with a fivefold volume of a solution containing $10 \mathrm{mg} / \mathrm{mL}$ WGA-SPA-beads (Amersham Pharmacia Biotech) resuspended with assay buffer. The binding assays were carried out in triplicate for $1 \mathrm{~h}$ at room temperature in a total volume of $250 \mu \mathrm{L}$. In each well of a 96-well white plate with a clear bottom (Corning Costar $\mathrm{GmbH}$ ) either 5 $\mu \mathrm{L}$ of $50 \mu \mathrm{M}$ N/OFQ in $25 \%$ DMSO (unspecific binding) or $5 \mu \mathrm{L}$ of $100 \mathrm{nM}$ N/OFQ in 25\% DMSO (reference) or $5 \mu \mathrm{L}$ TE buffer as a vehicle (maximal binding) or $5 \mu \mathrm{L}$ Spiegelmer solution, $100 \mu \mathrm{L}$ assay buffer, and $25 \mu \mathrm{L}$ of $5 \mathrm{nM}$ [ leucyl- $\left.{ }^{3} \mathrm{H}\right]-\mathrm{N} / \mathrm{OFQ}$ in assay buffer containing $10 \%$ ethanol were added. To start the assay, $20 \mu \mathrm{L}$ membrane dilution (containing $10.62 \mu \mathrm{g}$ membrane) and $1 \mathrm{mg}$ WGA-SPA-beads in $100 \mu \mathrm{L}$ assay buffer were added to each well.
Plates were top sealed and incubated by shaking for $1 \mathrm{~h}$ at $25^{\circ} \mathrm{C}$. Nonspecific binding was defined in the presence of $1 \mu \mathrm{M}$ N/OFQ. The bound activity was determined using a Wallac 450 Micro-Beta scintillation counter (Wallac). Data were analyzed by nonlinear regression analysis using Figure P (Version 2.98, Biosoft).

\section{N/OFQ-stimulated $G$ protein activation by human ORL1 receptor}

To study the G protein activation by the human ORL1 receptor, a CHO-K1 cell line expressing the receptor (Wnendt et al. 1999) was used to characterize the Spiegelmers in a $\left.{ }^{35} \mathrm{~S}\right] \mathrm{GTP} \gamma \mathrm{S}$-binding assay. The CHO-K1 cells were grown to confluence in 10 flasks of $175 \mathrm{~cm}^{2}$, washed with PBS, and scraped from the plates in $10 \mathrm{~mL}$ of PBS. After pelleting the cells by centrifugation for $10 \mathrm{~min}$ at $1000 \mathrm{~g}$ and $4^{\circ} \mathrm{C}$, the supernatant was discarded and the cells were frozen at $-80^{\circ} \mathrm{C}$. The cells were thawed in $30 \mathrm{~mL}$ of ice-cold homogenization buffer $(50 \mathrm{mM}$ Tris- $\mathrm{HCl}$ at $\mathrm{pH} 7.0,2.5 \mathrm{mM}$ EDTA, $0.1 \mathrm{mM}$ PMSF), kept for $10 \mathrm{~min}$ on ice, and homogenized with a Potter S ( $800 \mathrm{rpm}$, seven strokes with a Teflon pestle). The cell suspension was pelleted by centrifugation for $10 \mathrm{~min}$ at $750 \mathrm{~g}$. Nuclei were removed by resuspending the cells in $15 \mathrm{~mL}$ of $50 \mathrm{mM}$ Tris-HCl ( $\mathrm{pH}$ 7.0) using a polytron homogenizer followed by centrifugation for $10 \mathrm{~min}$ at $750 \mathrm{~g}$ and $4^{\circ} \mathrm{C}$. Membranes were collected by centrifuging the supernatants for $30 \mathrm{~min}$ at $75,000 \mathrm{~g}$ and $4^{\circ} \mathrm{C}$ and resuspended in $25 \mathrm{~mL}$ of $50 \mathrm{mM}$ Tris- $\mathrm{HCl}(\mathrm{pH} \mathrm{7.0)}$ ), followed by a second centrifugation for $30 \mathrm{~min}$ at $75,000 \mathrm{~g}$ and $4^{\circ} \mathrm{C}$ and final resuspension in $2 \mathrm{~mL}$ of $50 \mathrm{mM}$ Tris- $\mathrm{HCl}(\mathrm{pH} 7.0)$ and $0.35 \mathrm{mM}$ sucrose. The protein concentration was determined by using the Bicinchoninic Acid (BCA) Assay (Pierce) according to the manufacturer's protocol, and the protein was stored at $-80^{\circ} \mathrm{C}$. For the assay, the membranes were thawed rapidly, diluted in $20 \mathrm{mM}$ HEPES ( $\mathrm{pH}$ 7.4), and resuspended by homogenization. For each assay, $10 \mu \mathrm{g}$ membrane proteins were incubated in a solution containing $20 \mathrm{mM}$ HEPES (pH 7.4), $10 \mathrm{mM} \mathrm{MgCl}_{2}, 100 \mathrm{mM}$ $\mathrm{NaCl}, 1 \mathrm{mM}$ EDTA, $10 \mu \mathrm{M}$ GDP, $0.4 \mathrm{mM}\left[{ }^{35} \mathrm{~S}\right] \mathrm{GTP} \gamma \mathrm{S}$ (Amersham Pharmacia Biotech), $1 \mathrm{mg}$ WGA-PVT-beads (Amersham Pharmacia Biotech), and the agonist in a final volume of $200 \mu \mathrm{L}$. After 45 min of incubation at room temperature, the assay plate was centrifuged for $10 \mathrm{~min}$ at $3200 \mathrm{rpm}$. The bound activity was determined using a Wallac 450 Micro-Beta scintillation counter. Data were analyzed using Figure $\mathrm{P}$ (Version 2.98, Biosoft). The $\left[{ }^{35} \mathrm{~S}\right] \mathrm{GTP} \gamma \mathrm{S}$ incorporation was determined in two independent experiments, each carried out in triplicate.

\section{N/OFQ-stimulated $G$ protein activation by $\mu$-opioid receptor}

To study the $\mathrm{G}$ protein activation by the $\mu$-opioid receptor, membranes from $\mathrm{CHO}-\mathrm{K} 1$ cells transfected with human $\mu$-opioid receptor (Receptor Biology, Inc.) were used to analyze $\left[{ }^{35} \mathrm{~S}\right] \mathrm{GTP} \gamma \mathrm{S}$ binding. The assay conditions and the subsequent data analysis were identical to the above described ORL1-GTP $\gamma$ S-assay.

\section{Measurement of membrane currents of X. laevis oocytes}

Bags of the ovary of the African clawed frog X. laevis (anaesthetized with ice and $0.1 \% 3$-aminobenzoic acid ethyl ester) were surgically removed and placed in nominally $\mathrm{Ca}^{2+}$-free saline solution (10 mM HEPES at pH 7.6, $96 \mathrm{mM} \mathrm{NaCl}, 2 \mathrm{mM} \mathrm{KCl}, 1 \mathrm{mM}$ 
$\mathrm{MgCl}_{2}$ ). Oocytes were either singled out by hand, using a platinum loop, or obtained by enzymatic treatment to remove their follicular envelopes (collagenase A, 1.9 units/10 mL, 30-40 min), and stored in modified Ringer solution containing $1.8 \mathrm{mM}$ calcium at $4^{\circ} \mathrm{C}$ up to $7 \mathrm{~d}$. Complementary RNA (cRNA, $25 \mathrm{ng} / 25 \mathrm{~nL} \mathrm{H}_{2} \mathrm{O}$ ) was injected into the oocytes with the help of a microscope using a pneumatic transjector (5246, Eppendorf-Netheler-Hinz GmbH) and a micromanipulator (MMJ, Märzhäuser). The cRNA-injected oocytes were then incubated for $48-72 \mathrm{~h}$ at $18^{\circ} \mathrm{C}$ for translation, processing, and embedding of the mature proteins into the cell membrane, before the electrophysiological experiments were carried out. DEPC-injected or native oocytes were used as controls (mock-injected oocytes). Single oocytes were placed on a plastic grid in an organ bath of about $1 \mathrm{~mL}$ that was built into a Perspex block that also contained a main reservoir of $100 \mathrm{~mL}$ modified Ringer solution (5 mM HEPES at $\mathrm{pH} 7.5,96 \mathrm{mM} \mathrm{NaCl}, 2 \mathrm{mM}$ $\mathrm{KCl}, 1 \mathrm{mM} \mathrm{MgCl}_{2}, 1.8 \mathrm{mM} \mathrm{CaCl}_{2}$ ) that was cooled to $20^{\circ} \mathrm{C}$. Communication between the two compartments was provided by connecting bores through which the fluids were driven by gas pressure $\left(\mathrm{O}_{2}\right)$. Thereby, substances could be easily added to or removed from the main reservoir by a rapid fluid exchange without mechanically or electrically disturbing the test compartment. Conventional micropipettes were made from borosilicate glass (Science Products) filled with $3 \mathrm{M} \mathrm{KCl}$. For voltage clamping, two electrodes whose tips were broken down to larger diameters, yielding resistances between 0.8 and $1.2 \mathrm{M} \Omega$, were inserted into the same oocyte under microscopic control. The two-electrode voltage clamp was performed as described before (Nawrath et al. 2000). All measurements were carried out in conjunction with a TEC05 two-electrode voltage-clamp amplifier (NPI Electronics). Data were stored on a DOS-compatible microcomputer running pClamp 5.7 software (Axon Instruments Inc.) in conjunction with an AD-DA converter (DigiData 1200, Axon Instruments Inc.) that was also used for the generation of voltage commands and data analysis. Experiments were excluded from analysis when leak currents increased $>10 \%$, thus indicating membrane damage at the sites of impalements. As fast changes in membrane ion conductances were not evident in response to any voltage clamp jumps, the currents were not electronically compensated for membrane capacity or resistance. The data are presented as original recordings or means \pm S.E.M. Statistical analysis was performed using ANOVA or paired t test, as appropriate. $P$ values $<0.05$ were considered significant.

\section{ACKNOWLEDGMENTS}

We are indebted to Elisabeth Moyroud, Stefanie Hoffmann, and Sebastian Heintze for synthesis of phosphoramidite building blocks and resins, to Gabi Anlauf, Martina Lira, and Jenny Kögler for oligonucleotide synthesis, to Petra Bernsdorf, Margit Kolbinger, and Rita Bleise for biochemical and biophysical assistance, and to Susanna Biermann for GTP $\gamma \mathrm{S}$ assays. In addition, we thank Thomas Rupp, Jens Peter Fürste for discussions, and we are grateful to Michael G. Courtney for discussions and support. This work was supported by BMBF grant Nr. 01 GG 9818/0.

The publication costs of this article were defrayed in part by payment of page charges. This article must therefore be hereby marked "advertisement" in accordance with 18 USC section 1734 solely to indicate this fact.
Received September 12, 2003; accepted November 7, 2003.

\section{REFERENCES}

Antao, V.P., Lai, S.Y., and Tinoco Jr., I. 1991. A thermodynamic study of unusually stable RNA and DNA hairpins. Nucleic Acids Res. 19: 5901-5905.

Bloms-Funke, P., Gillen, C., Schuettler, A.J., and Wnendt, S. 2000. Agonistic effects of the opioid buprenorphine on the nociceptin/ OFQ receptor. Peptides 21: 1141-1146.

Brody, E.N. and Gold, L. 2000. Aptamers as therapeutic and diagnostic agents. J. Biotechnol. 74: 5-13.

Burnside, J.L., Rodriguez, L., and Toll, L. 2000. Species differences in the efficacy of compounds at the nociceptin receptor (ORL1). Peptides 21: 1147-1154.

Calo, G., Bigoni, R., Rizzi, A., Guerrini, R., Salvadori, S., and Regoli, D. 2000a. Nociceptin/orphanin FQ receptor ligands. Peptides 21: 935-947.

Calo, G., Guerrini, R., Bigoni, R., Rizzi, A., Marzola, G., Okawa, H., Bianchi, C., Lambert, D.G., Salvadori, S., and Regoli, D. 2000b. Characterization of $[\mathrm{Nphe}(1)]$ nociceptin $(1-13) \mathrm{NH}(2)$, a new selective nociceptin receptor antagonist. Br. J. Pharmacol. 129: 11831193.

Calo, G., Guerrini, R., Rizzi, A., Salvadori, S., and Regoli, D. 2000c. Pharmacology of nociceptin and its receptor: A novel therapeutic target. Br. J. Pharmacol. 129: 1261-1283.

Calo, G., Rizzi, A., Bigoni, R., Guerrini, R., Salvadori, S., and Regoli, D. 2002. Pharmacological profile of nociceptin/orphanin FQ receptors. Clin. Exp. Pharmacol. Physiol. 29: 223-228.

Convery, M.A., Rowsell, S., Stonehouse, N.J., Ellington, A.D., Hirao, I., Murray, J.B., Peabody, D.S., Phillips, S.E., and Stockley, P.G. 1998. Crystal structure of an RNA aptamer-protein complex at 2.8 A resolution. Nat. Struct. Biol. 5: 133-139.

Darland, T. and Grandy, D.K. 1998. The orphanin FQ system: An emerging target for the management of pain? Br. J. Anaesth. 81: 29-37.

Darland, T., Heinricher, M.M., and Grandy, D.K. 1998. Orphanin $\mathrm{FQ} /$ nociceptin: A role in pain and analgesia, but so much more. Trends Neurosci. 21: 215-221.

Ehresmann, C., Baudin, F., Mougel, M., Romby, P., Ebel, J.P., and Ehresmann, B. 1987. Probing the structure of RNAs in solution. Nucleic Acids Res. 15: 9109-9128.

Ellington, A.D. and Szostak, J.W. 1990. In vitro selection of RNA molecules that bind specific ligands. Nature 346: 818-822.

Gold, L. 1995. Oligonucleotides as research, diagnostic, and therapeutic agents. J. Biol. Chem. 270: 13581-13584.

Green, L.S., Jellinek, D., Bell, C., Beebe, L.A., Feistner, B.D., Gill, S.C., Jucker, F.M., and Janjic, N. 1995. Nuclease-resistant nucleic acid ligands to vascular permeability factor/vascular endothelial growth factor. Chem. Biol. 2: 683-695.

Griebel, G., Perrault, G., and Sanger, D.J. 1999. Orphanin FQ, a novel neuropeptide with anti-stress-like activity. Brain Res. 836: 221-224.

Grisel, J.E. and Mogil, J.S. 2000. Effects of supraspinal orphanin FQ/ nociceptin. Peptides 21: 1037-1045.

Guerrini, R., Calo, G., Rizzi, A., Bigoni, R., Bianchi, C., Salvadori, S., and Regoli, D. 1998. A new selective antagonist of the nociceptin receptor. Br. J. Pharmacol. 123: 163-165.

Henderson, G. and McKnight, A.T. 1997. The orphan opioid receptor and its endogenous ligand-Nociceptin/orphanin FQ. Trends Pharmacol. Sci. 18: 293-300.

Hofacker, I.L., Fontana, W., Stadler, P.F., Bonhoeffer, S., Tacker, M., and Schuster, P. 1994. Fast folding and comparison of RNA secondary structures. Monatshefte $f$. Chemie. 125: 167-188.

Ikeda, K., Kobayashi, K., Kobayashi, T., Ichikawa, T., Kumanishi, T., Kishida, H., Yano, R., and Manabe, T. 1997. Functional coupling of the nociceptin/orphanin FQ receptor with the G- protein-activated K+ (GIRK) channel. Brain Res. Mol. Brain Res. 45: 117-126. James, W. 2000. Aptamers. In Encyclopedia of analytical chemistry (ed. 
R.A. Meyers), pp. 1-23. Wiley, Chichester, UK.

Jayasena, S.D. 1999. Aptamers: An emerging class of molecules that rival antibodies in diagnostics. Clin. Chem. 45: 1628-1650.

Kamei, J., Ohsawa, M., Kashiwazaki, T., and Nagase, H. 1999. Antinociceptive effects of the ORL1 receptor agonist nociceptin/orphanin FQ in diabetic mice. Eur. J. Pharmacol. 370: 109-116.

Klussmann, S., Nolte, A., Bald, R., Erdmann, V.A., and Furste, J.P. 1996. Mirror-image RNA that binds D-adenosine. Nat. Biotechnol. 14: 1112-1115.

Kubik, M.F., Bell, C., Fitzwater, T., Watson, S.R., and Tasset, D.M. 1997. Isolation and characterization of $2^{\prime}$-fluoro-, $2^{\prime}$-amino-, and $2^{\prime}$-fluoro-/amino-modified RNA ligands to human IFN- $\gamma$ that inhibit receptor binding. J. Immunol. 159: 259-267.

Leva, S., Lichte, A., Burmeister, J., Muhn, P., Jahnke, B., Fesser, D., Erfurth, J., Burgstaller, P., and Klussmann, S. 2002. GnRH binding RNA and DNA Spiegelmers. A novel approach toward GnRH antagonism. Chem. Biol. 9: 351-359.

Lin, Y., Qiu, Q., Gill, S.C., and Jayasena, S.D. 1994. Modified RNA sequence pools for in vitro selection. Nucleic Acids Res. 22: 52295234.

Meunier, J.C. 1997. Nociceptin/orphanin FQ and the opioid receptorlike ORL1 receptor. Eur. J. Pharmacol. 340: 1-15.

Meunier, J.C. 2000. The potential therapeutic value of nociceptin receptor agonists and antagonists. Exp. Opin. Ther. Patents. 10: 371-388.

Meunier, J.C., Mollereau, C., Toll, L., Suaudeau, C., Moisand, C., Alvinerie, P., Butour, J.L., Guillemot, J.C., Ferrara, P., Monsarrat, B., et al. 1995. Isolation and structure of the endogenous agonist of opioid receptor-like ORL1 receptor. Nature 377: 532-535.

Mogil, J.S. and Pasternak, G.W. 2001. The molecular and behavioral pharmacology of the orphanin $\mathrm{FQ} /$ nociceptin peptide and receptor family. Pharmacol. Rev. 53: 381-415.

Mollereau, C. and Mouledous, L. 2000. Tissue distribution of the opioid receptor-like (ORL1) receptor. Peptides 21: 907-917.

Monteillet-Agius, G., Fein, J., Anton, B., and Evans, C.J. 1998. ORL-1 and $\mu$ opioid receptor antisera label different fibers in areas involved in pain processing. J. Comp. Neurol. 399: 373-383.

Nawrath, H., Wegener, J.W., Rupp, J., Habermeier, A., and Closs, E.I. 2000. Voltage dependence of $L$-arginine transport by hCAT-2A and hCAT-2B expressed in oocytes from Xenopus laevis. Am. J. Physiol. Cell Physiol. 279: C1336-1344.

Neal Jr., C.R., Mansour, A., Reinscheid, R., Nothacker, H.P., Civelli, O., and Watson Jr., S.J. 1999. Localization of orphanin FQ (nociceptin) peptide and messenger RNA in the central nervous system of the rat. J. Comp. Neurol. 406: 503-547.

Nieuwlandt, D., Wecker, M., and Gold, L. 1995. In vitro selection of RNA ligands to substance P. Biochemistry 34: 5651-5659.

Nolte, A., Klussmann, S., Bald, R., Erdmann, V.A., and Furste, J.P. 1996. Mirror-design of $L$-oligonucleotide ligands binding to $L$ arginine. Nat. Biotechnol. 14: 1116-1119.

Pagratis, N.C., Bell, C., Chang, Y.F., Jennings, S., Fitzwater, T., Jellinek, D., and Dang, C. 1997. Potent 2'-amino-, and 2'-fluoro-2'-deoxyribonucleotide RNA inhibitors of keratinocyte growth factor. Nat. Biotechnol. 15: 68-73.

Reinscheid, R.K., Nothacker, H.P., Bourson, A., Ardati, A., Henningsen, R.A., Bunzow, J.R., Grandy, D.K., Langen, H., Monsma Jr., F.J., and Civelli, O. 1995. Orphanin FQ: A neuropeptide that activates an opioidlike G protein-coupled receptor. Science 270: 792794.

Reinscheid, R.K., Nothacker, H., and Civelli, O. 2000. The orphanin FQ/nociceptin gene: Structure, tissue distribution of expression and functional implications obtained from knockout mice. Peptides 21: 901-906.

Rizzi, A., Bigoni, R., Marzola, G., Guerrini, R., Salvadori, S., Regoli, D., and Calo, G. 2000. The nociceptin/orphanin FQ receptor antagonist, [Nphe1] NC(1-13) NH2, potentiates morphine analgesia. Neuroreport 11: 2369-2372.

Robertson, D.L. and Joyce, G.F. 1990. Selection in vitro of an RNA enzyme that specifically cleaves single-stranded DNA. Nature 344: $467-468$.

Rover, S., Adam, G., Cesura, A.M., Galley, G., Jenck, F., Monsma Jr., F.J., Wichmann, J., and Dautzenberg, F.M. 2000a. High-affinity, non-peptide agonists for the orl1 (orphanin fq/nociceptin) receptor. J. Med. Chem. 43: 1329-1338.

Rover, S., Wichmann, J., Jenck, F., Adam, G., and Cesura, A.M. 2000 b. ORL1 receptor ligands: Structure-activity relationships of 8-cycloalkyl-1-phenyl-1,3,8-triaza-spiro[4.5]decan-4-ones. Bioorg. Med. Chem. Lett. 10: 831-834.

Rowsell, S., Stonehouse, N.J., Convery, M.A., Adams, C.J., Ellington, A.D., Hirao, I., Peabody, D.S., Stockley, P.G., and Phillips, S.E. 1998. Crystal structures of a series of RNA aptamers complexed to the same protein target. Nat. Struct. Biol. 5: 970-975.

Salvadori, S., Picone, D., Tancredi, T., Guerrini, R., Spadaccini, R., Lazarus, L.H., Regoli, D., and Temussi, P.A. 1997. Solution conformation of nociceptin. Biochem. Biophys. Res. Commun. 233: 640-643.

Sambrook, J., Fritsch, E.J., and Maniatis, T. 1989. Molecular cloning: A laboratory manual. Cold Spring Harbor Laboratory Press, Cold Spring Harbor, NY.

Tian, J.H. and Han, J.S. 2000. Functional studies using antibodies against orphanin FQ/nociceptin. Peptides 21: 1047-1050.

Tian, J.H., Xu, W., Fang, Y., Mogil, J.S., Grisel, J.E., Grandy, D.K., and Han, J.S. 1997. Bidirectional modulatory effect of orphanin FQ on morphine-induced analgesia: Antagonism in brain and potentiation in spinal cord of the rat. Br. J. Pharmacol. 120: 676-680.

Tian, J.H., Zhang, W., Fang, Y., Xu, W., Grandy, D.K., and Han, J.S. 1998. Endogenous orphanin FQ: Evidence for a role in the modulation of electroacupuncture analgesia and the development of tolerance to analgesia produced by morphine and electroacupuncture. Br. J. Pharmacol. 124: 21-26.

Toulmé, J.J. 2000. Aptamers: Selected oligonucleotides for therapy. Curr. Opin. Mol. Ther. 2: 318-324.

Tuerk, C. and Gold, L. 1990. Systematic evolution of ligands by exponential enrichment: RNA ligands to bacteriophage T4 DNA polymerase. Science 249: 505-510.

Urata, H., Ogura, E., Shinohara, K., Ueda, Y., and Akagi, M. 1992. Synthesis and properties of mirror-image DNA. Nucleic Acids Res. 20: 3325-3332.

Vater, A. and Klussmann, S. 2003. Toward third-generation aptamers: Spiegelmers and their therapeutic prospects. Curr. Opin. Drug Disc. Devel. 6: 253-261.

Williams, K.P., Liu, X.H., Schumacher, T.N., Lin, H.Y., Ausiello, D.A., Kim, P.S., and Bartel, D.P. 1997. Bioactive and nuclease-resistant L-DNA ligand of vasopressin. Proc. Natl. Acad. Sci. 94: 1128511290.

Wilson, D.S. and Szostak, J.W. 1999. In vitro selection of functional nucleic acids. Аnnu. Rev. Biochem. 68: 611-647.

Wnendt, S., Kruger, T., Janocha, E., Hildebrandt, D., and Englberger, W. 1999. Agonistic effect of buprenorphine in a nociceptin/OFQ receptor-triggered reporter gene assay. Mol. Pharmacol. 56: 334-338.

$\mathrm{Xu}, \mathrm{W}$. and Ellington, A.D. 1996. Anti-peptide aptamers recognize amino acid sequence and bind a protein epitope. Proc. Natl. Acad. Sci. USA. 93: 7475-7480.

Ye, X., Gorin, A., Frederick, R., Hu, W., Majumdar, A., Xu, W., McLendon, G., Ellington, A., and Patel, D.J. 1999. RNA architecture dictates the conformations of a bound peptide. Chem. Biol. 6: 657-669. 

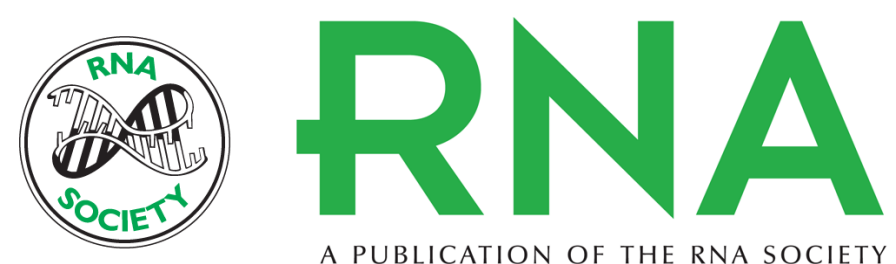

A PUBLICATION OF THE RNA SOCIETY

\section{Biostable aptamers with antagonistic properties to the neuropeptide nociceptin/orphanin FQ}

DIRK FAULHAMMER, BERND ESCHGFÄLLER, SANDRA STARK, et al.

RNA 2004 10: 516-527

References This article cites 58 articles, 9 of which can be accessed free at: http://rnajournal.cshlp.org/content/10/3/516.full.html\#ref-list-1

\section{License}

Email Alerting Receive free email alerts when new articles cite this article - sign up in the box at the Service top right corner of the article or click here. 